\title{
AL-NABIY AL-UMMIY DALAM TELAAH HISTORIS-SEMIOTIK
}

\author{
Aris Fauzan \\ Universitas Muhammadiyah Yogyakarta \\ mas_arisfauzan@umy.ac.id
}

\begin{abstract}
This article tries to reveal another meaning to the word al-nabiy al-ummiy in the context of historic-Sufistic. Among Indonesian mufassirs al-nabiy al-ummiy means less read and write, although there are other muslim scholars who understand that the Prophet Muhammad does not know how to read and write. Based on this latter view it becomes an apologetic argument that all the revelations revealed to the Prophet Muhammad are independently. There were not influenced by the previous traditions and religious cultures. To find the meaning beyond the conventional meaning above, the author tries to trace the historical background before and during Muhammad's time by using descriptive analytic-historical and sufistic. The result of this discussion of the author finds that beyond the common sense al-nabiy al-ummiy can be understood by: first, that Muhammad saw as the perfect person he became the source (babon), polecy (policy), and wisdom (wisdom) both vertical and horizontal among the people. Secondly, based on the historical reality of the proud Arab nation if it is attributed to the lineage of Mother's side, it affirms that the prophet Muhammad is an honorable man. Third, al-nabiy al-ummiy became one of the visions of Islam as a motherly religion that women should be honored and get their rights. Fourth, al-nabiy al-ummiy as proof that the prophet Muhammad gave strict laws against the mothers (of a husband) who can not be passed on to the children of his old wife.
\end{abstract}

Keywords: al-nabiy al-ummiy, the source (baboon), mother's nasab

\begin{abstract}
Abstrak
Artikel ini berusaha untuk mengungkap makna lain pada kata al-nabiy al-ummiy dalam konteks historis sufistik. Al-nabiy al-ummiy di kalangan mufassir Indonesia mengartikan kurang pandai membaca dan menulis, meskipun ada pula ulama lain yang memahami keadaan Nabi Muhammad yang tidak tahu baca tulis. Pada pendapat yang terakhir ini dijadikan sebagai argumentasi apologetis bahwa seluruh wahyu yang diturunkan kepada Nabi Muhammad terlepas dari pengaruh tradisi dan budaya agamaagama yang sudah ada. Untuk mengungkap makna di luar makna konvensional di atas, penulis berusaha melacak realitas historis sebelum dan pada saat Muhammad saw dengan menggunakan penjelasan deskriptif analitis-historis dan sufistik . Hasil dari pembahasan ini penulis mengungkap, bahwa di luar makna yang umum,al-nabiy alummiy bisa dipahami dengan: pertama, bahwa Muhammad saw sebagai pribadi yang sempurna dia menjadi sumber (babon), polecy (kebijakan), dan wisdom (kebijaksanaan) baik yang bersifat vertikal maupun horizontal di kalangan umatnya. Kedua, berpijak pada realitas kesejarahan bangsa Arab yang bangga jika dinasabkan pada garis keturunan dari pihak Ibu, hal ini menegaskan bahwa nabi Muhammad
\end{abstract}

FOKUS : Jurnal Kajian Keislaman dan Kemasyarakatan Vol. 3, No. 1, 2018

P3M Sekolah Tinggi Agama Islam Negeri (STAIN) Curup - Bengkulu

Available online: http://journal.staincurup.ac.id/index.php/JF

p-ISSN 2548-334X, e-ISSN 2548-3358 
adalah orang terhormat. Ketiga, al-nabiy al-ummiy menjadi salah satu visi keislaman sebagai agama keibuan bahwa perempuan harus terhormat dan mendapatkan haknya. Keempat, al-nabiy al-ummiy sebagai bukti bahwa nabi Muhammad memberi hukum tegas terhadap ibu-ibu (dari seorang suami) yang tidak boleh lagi diwariskan kepada anak-anak dari istri tuanya.

Kata Kunci: al-nabiy al-ummiy, sumber (babon), nasab ibu

\section{PENDAHULUAN}

Diskusi tentang makna dan maksud pada kata an-Nabiy al-Ummiy tidak akan pernah berhenti, sebagaimana terus adanya pertanyaan serta tantangan berbagai kalangan yang mempersoalkan keautentikan dan keabadian al-Qur'an. Isu an-Nabiy al-Ummiy bukan hanya menjadi pembicaraan di kalangan umat Islam, tetapi juga dipersoalkan secara akademik logis di kalangan kaum Orientalis. ${ }^{1}$ Pendapat yang paling masyhur menyebutkan maksud dari an-nabiy al-ummiy nabi yang buta huruf. $^{2}$

Pertanyaan mereka ini bukan tanpa alasan, karena selama nabi Muhammad berada di Madinah, beberapa kali melakukan revisi terhadap Piagam Madinah (as-Shahifah al-Madinah atau al-Mitsaq al-Madinah) yang mana mulai dari ketentuan awal hingga akhir dituangkan dalam bentuk tulisan. ${ }^{3}$ Piagam Madinah terus dilakukan revisi sesuai dengan dinamika konflik dan bertambahnya kelompok-kelompok yang terlibat dalam konflik sosial-politik di Madinah. Pada mulanya Piagam tersebut hanya diterima oleh kalangan kecil umat Yahudi Madinah, namun setelah umat Islam mengalami perkembangan yang pesat di Madinah, akhirnya

\footnotetext{
${ }^{1}$ Wan Z. Kamaruddin bin Wan Ali, “Konsep Ummi Nabi Muhammad saw dalam Perspektif al-Qur'an”, Jurnal Ushuluddin, Vol. 7, 1998, hlm. 147-162.

2 Lihat Muhammad Rawas Qal'ahji, Syakhshiyah Muhammad saw: Mengupas Keunikan Sifat-sifat Rasulullah saw, terj. Uwais al-Qarni (Bogor: Pustaka Thariqul Izzah, 2013), hlm. 55-56.

3 Badri Yatim, "Muhammad SAW di Madinah," dalam Taufik Abdullah, Ensiklopedi Tematis Dunia Islam: Akal dan Awal (Jakarta: PT Ichtiar Baru van Hoeve, 2002),hlm. 121. Piagam Madinah ini berfungsi sebagai semacam undang-undang politik kemasyarakatan bagi semua golongan yang ada di kota Madinah (Yatsrib). Piagam yang terdiri dari 70 pasal - ini tidak ditulis pada waktu bersamaan; antara pasal-pasal pada satu bagian dan bagian lain sering terdapat pengulangan atau penjelasan lebih terperinci tentang persoalan yang sudah dikandung di dalamnya. Ibid.
} 
suku-suku besar Yahudi Madinah seperti Bani Qainuqa, Bani Nadir, dan Bani Quraizah ikut menandatangani perjanjian tersebut. ${ }^{4}$

Dengan nalar sederhana sebuah aturan yang terus mengalami perubahan dan penambahan mustakhil direnungkan dan ditulis oleh orang-orang yang tidak paham baca dan tulis. ${ }^{5}$ Piagam Madinah yang sarat dengan tulis menulis menggambarkan bahwa budaya tulis menulis pasca kerasulan Muhammad saw menjadi semakin kuat. Jika an-nabiy alummiy diartikan dengan nabi yang buta huruf, berlawanan dengan keyakinan bahwa seorang utusan Allah yang diyakini memiliki kecerdasan di atas rata-rata para umatnya, namun tidak bisa memahami simbol berupa tulisan yang diproduksi suatu kebudayaan.

Memang terdapat ayat yang dipahami sebagai dukungan akan kebuta hurufan Muhammad saw. ${ }^{6}$ Namun, pembacaan sejarah kerasulan dan kenabian Muhammad saw selama menerima wahyu dalam rentang kurang lebih 22 tahun mustahil menutup akses baginya tetap dalam keadaan buta huruf. Penegasan para ulama' yang menjelaskan bahwa keadaan an-Nabiy al-Ummiy pada Muhammad saw itu sudah cukup sebagai bukti bahwa beliau tidak mungkin menulis dan membuat al-Qur'an dari lisan dan tangannya sendiri dan mampu menghentikan tuduhan para penentang kenabian Muhammad saw. ${ }^{7}$

Selain pertanyaan-pertayaan di atas keadaan Muhammad saw sebagai an-nabiy al-ummiy memberi kesan bahwa hal itu bertolak belakang dengan sejumlah ayat-ayat al-Qur'an yang berhubungan dengan alat tulis,

\footnotetext{
${ }^{4}$ Badri Yatim, Op. cit, hlm. 122. .

${ }^{5}$ Apalagi dalam proses penyempurnaannya Piagam Madinah ini terdiri dari empat bagian yang setiap bagian berisi tulisan aturan-aturan baru, baik aturan untuk umat Islam sendiri maupun aturan untuk umat Islam dengan non Islam.

${ }^{6}$ Awal turunnya wahyu al-Qur'an adalah surat al-Alaq ayat 1-5. Dalam peristiwa setengah mimpi itu oleh malaikat Jibril Sang Pengantar wahyu, Muhammad saw diminta untuk membaca (iqra' atau recite). Namun Muhammad saw menjawab "Maa anaa bi qaariin."

${ }_{7}$ Pertanyaan lainnya bisa munculnya, mislanya: Sekiranya Muhammad saw kemudian mengenal simbol-simbol bahasa Arab, kira-kira pada tahun ke berapa beliau mulai mengakrabi tulisan? Apakah orang-orang yang bertanya atau memiliki pemahaman maksud an-nabiy al-ummiy di luar otoritas dan mayoritas ulama dianggap sebagai orang yang keluar dari Islam?
} 
tindakan tulis menulis. ${ }^{8}$ Ayat-ayat tersebut memberi gambaran logis baik secara kultur maupun personal nabi Muhammad hidup dalam lingkungan tradisi-tradisi umat beragama (Yahudi maupun Kristen) yang terbiasa dengan budaya tulis.

Bermula dari latar belakang di atas, artikel ini berusaha untuk mengungkap makna lain an-nabiy al-ummiy dalam perspektif di luar pemahaman normatif teologis, yaitu dengan mahaman sejarah dan sufistik. $^{9}$

\section{PEMBAHASAN}

\section{Pengertian al-Nabiy al-Ummiy}

Kata al-Nabiy al-Ummiy terdiri dua kata al-Nabiy dan al-Ummiy. Kedua kata ini dua kali disebutkan dalam al-Qur'an. Adapun pengertian al-ummiy menurut bahasa dan istilah sebagaimana dikemukakan sejumlah ahli berikut ini:

1. An-nabiy: a prophet. A prophet is a friend of Allah (wali) who possesses unique knowledge of the Unseen World. ${ }^{10}$ al-mukhbir 'an Allah $^{11}$ (pembawa kabar dari Allah).

2. Ummiy: man laa yaqra' wa laa yaktubu, ghairu muta'allam (tidak terdidik); rajulun ummiyun $\rightarrow$ man laysa min ahli al-kitaab; ${ }^{12}$ hairu

${ }^{8}$ Uraian ayat-ayat terkait tulis menulis sebagaimana tertuang dalam Q.S. alQalam/68: 1 dan 47; al-'Alaq/96: 4; al-Kahfi/18: 109; Luqman/31: 27; al-Anbiya/21: 105; al-Baqarah/2: 282; al-Ankabut/29: 48; al-Maidah/5:110. Kedua, kritikan terhadap budaya tulis menulis yang dilakukan oleh umat sebelum Nabi Muhammad yang selanjutnya hasil karyanya itu mereka yakini sebagai firman Allah dan adanya arahan untuk berkomitmen pada tindakan mempercayai kitab-kitab sebelum al-Qur'an. Hal itu sebagaimana tertuang dalam Q.S. al-Baqarah/2: 4; al-Maidah/5: 48; dan al-Nahl/16: 6364.

${ }^{9}$ Sebagaimana yang sudah menjadi pemahaman umum bahwa cara para sufi dalam memahami ayat-ayat suci al-Qur'an tidak hanya berhenti pada makna harfiah, tetapi juga mengungkap makna kata perkata mengapa Allah memilih kata-kata tertentu di dalam al-Qur'an. Dan pilihan kata tertentu itu bukan hanya dipahami secara harfiah, tetapi terdapat makna lain yang luas dan dalam lagi.

${ }^{10}$ Amatullah Armstrong, Sufi Terminology: al-Qamus al-Sufi) the Mystical Language in Islam (Kuala Lumpur: A.S. Noordeen, 1995), hlm.166.

${ }^{11}$ Ahmad Warson Munawwir, al-Munawwir: Kamis Arab-Indonesia (Yogyakarta: Pondok Pesantren al-Munawwir Krapyak, 1984), hlm. 1472. 
muta'allam; Illiterate, uneducated, unlettered $;{ }^{13}$ ummiy $\rightarrow$ maternal, motherly, illiterate, uneducated. ${ }^{14}$ Al-Ummiy $\rightarrow$ yang tidak dapat membaca dan menulis; yang bodoh dan kasar; yang mengibu; keibuan; kebodohan; hal tak tahu baca tulis. ${ }^{15}$ Al-ummiy: man laa ya'rifu alkitaabah wa laa al-qiraah; al-ummiyah jahlu al-kitabah wa alqiraah. $^{16}$

3. al-Ummiy: unlettered. Ummi indicates the knower who, possessing a heart which is empty of outward intellectual learning, is pure vessel to receave "God-given" (ladunni) knowlegde or "unlettered knowledge" (al-ilm al-ummi). His heart is untainted. His love of Allah is total. His bondage is perfect. His hands are upturned in humality and need. In being "no thing" (la syai') Allah showers him with everything. ${ }^{17}$

4. A term used to refer to the Prophet Muhammad and variably translated as "the unlettered prophet," "the prophet sent to a people without a scripture," or "the prophet of the community of Muslims" (Quran 7:157). The term ummi derives from the noun umm, which means "mother," "source," or "foundation," as in the Quranic umm al-kitab (sourcebook, primordial book). Ummi may also mean "motherly," "uneducated," or "illiterate." The most common meaning of al-nabi al-ummi is "the unlettered prophet," which refers to the Prophet Muhammad's inability to create a major literary work such as the Quran. Some commentators have traced the term to the noun ummah, which refers to a primary community sharing a common religious orientation. In this sense, al-nabi al-ummi means "the

12 Ahmad Mukhtar 'Umar, Mu'jam al-Lughah al-'Arabiyyah al-Mu'ashir, alMujallad al-Awwal, (Kairo: Alam al-Kutub, 2007), hlm. 121.

${ }^{13}$ Rohi Baalbaki, al-Mawrid: Modern Arabic-English Dictionary (Libanon: Dar el Ilmlil Malayin,2001), hlm. 172.

${ }^{14}$ Hans Wehr, a Dictionary of Modern Written Arabic: Arabic-English (New York: Spoken Languge Service, 1976), hlm. 25.

${ }_{16}^{15}$ Ahmad Warson Munawwir, Op. cit, hlm. 43.

${ }^{16}$ Luis Ma'luf, Al-Munjid: fi al-Lughah wa al-A'laam (Beirut: Dar al-Masyriq, 1973), hlm. 17.

${ }^{17}$ Amatullah Armstrong, Op. cit, hlm.249. 
prophet sent to an unscripted community," or a community that has not yet received a scripture. ${ }^{18}$

5. The stress on his having been "unlettered" (ummi), i.e., unable to read and write, serves to bring out the fact that all his knowledge of the earlier prophets and of the messages transmitted by them was due to divine inspiration alone, and not to a familiarity with the Bible as such. $^{19}$

Secara simbolik maka nawiyah al-ummiy yang diambil dari kata alumm yang dalam terjemah bahasa Inggris adalah maternal. Maternal dalam kamus Webster diterjemahkan maternal dan maternity sebagai berikut:

1) characteristic of a mother or motherhood, motherly; 2) derived, received, or inherited from a mother; 3) related through the mother's side of the family (maternal grandparent).

Maternity: 1) the state of being a mother; motherhood; 2) the character or qualities of a mother; motherliness; 3) a maternity ward in a hospital. Adj. For a woman when pregnant or around the time of

\footnotetext{
${ }^{18}$ http://www.oxfordislamicstudies.com/article/opr/t125/e1680. Artinya Suatu istilah yang digunakan untuk merujuk kepada Nabi Muhammad dan secara beragam diterjemahkan sebagai "nabi yang tidak terlantar," "nabi yang dikirim kepada orangorang tanpa kitab suci," atau "nabi dari komunitas Muslim" (Al-Quran 7: 157). Istilah ummi berasal dari kata benda umm, yang berarti "ibu," "sumber," atau "fondasi," seperti dalam Quran umm al-kitab (buku sumber, buku primordial). Ummi bisa juga berarti "keibuan," "tidak berpendidikan," atau "buta huruf." Arti paling umum dari al-naby alummy adalah "nabi yang tidak terlantar," yang mengacu pada ketidakmampuan Nabi Muhammad untuk menciptakan karya sastra utama seperti Al-Qur'an. Beberapa komentator telah menelusuri istilah tersebut ke kata ummah, yang mengacu pada komunitas primer yang berbagi orientasi keagamaan umum. Dalam pengertian ini, alnabi al-ummi berarti "nabi yang dikirim ke komunitas tanpa naskah," atau komunitas yang belum menerima kitab suci.

${ }^{19}$ The Message of The Quran translated and explained by Muhammad Asad. Terjemahnya: Penekanan pada dirinya yang "tidak terselesaikan" (ummi), yaitu, tidak dapat membaca dan menulis, berfungsi untuk memunculkan fakta bahwa semua pengetahuannya tentang nabi-nabi sebelumnya dan pesan-pesan yang dikirimkan oleh mereka adalah karena inspirasi ilahi saja, dan tidak terbiasa dengan Alkitab seperti itu.
} 
giving birth (maternity dress, maternity leave); for care of woman giving birth and newborn babies (a maternity ward). ${ }^{20}$

Dalam the American College Dictinary, maternal, maternity diuraikan sebagai berikut:

Maternal: 1) of or pertaining to, befitting, having the qualities of, or being a mother; 2) derived from a mother; 3)related to a mother: his maternal aunt. Maternity: 1)state being a mother; motherhood; 2). motherlines. Maternity hospital: a hospital for the care of woman during confinement in childbirth. ${ }^{21}$

Berdasarkan pada definisi di atas secara umum sepakat bahwa alnabiy al-ummiy adalah pengertian yang secara khusus ditujukan kepada Muhammad saw sebagai nabi yang buta huruf. Dalam pemahaman lain sebagai nabi yang keibuan, nabi sebagai sumber, nabi sebagai dasar, nabi yang diturunkan kepada umat yang tidak punya kitab suci, kebodohan, seseorang yang tidak mempunyai kemampuan untuk membaca dan menulis. Hal-hal yang berhubungan dengan wahyu yang diturunkan kepada Muhammad saw, tidak ada hubungannya dengan tradisi-tradisi agama yang sudah ada sebelumnya (Yahudi dan Nasrani), semata-mata karena Allah. Namun dari pengertian di atas sedikit sekali yang mempunyai kecenderungan pada sumber atau fondasi (dasar). Bahkan bisa dikatakan ada semacam keseragaman - yang mengarah pada kesepatakan tidak tertulis - bahwa al-nabiy al-ummiy itu nabi yang buta huruf dan tidak mengerti baca tulis.

\section{An-Nabi al-Ummiy dalam Q.S. al-A'raf(7)}

Berikut ini terjemah lengkap Q.S. al-A'raf/7: 157-158:

Pertama, Q.S. al-A'raf (7):157. (Yaitu) orang-orang yang mengikut Rasul, Nabi yang ummi yang (namanya) mereka dapati tertulis di dalam Taurat dan Injil yang ada di sisi mereka, yang menyuruh mereka

\footnotetext{
${ }^{20}$ Victoria Neufeldt (ed.), Webster's New World College Dictionary, (USA: MacMillan, 1996), hlm. 835.

${ }^{21}$ C.L. Barnjart (ed.), The American College Diactionary (New York: Random House, 1960), hlm.751.
} 
mengerjakan yang ma'ruf dan melarang mereka dari mengerjakan yang mungkar dan menghalalkan bagi mereka segala yang baik dan mengharamkan bagi mereka segala yang buruk dan membuang dari mereka beban-beban dan belenggu-belenggu yang ada pada mereka ${ }^{22}$. Maka orang-orang yang beriman kepadanya, memuliakannya, menolongnya, dan mengikuti cahaya yang terang yang diturunkan kepadanya (Al Quran), mereka itulah orang-orang yang beruntung.

Kedua, Q.S. al-A'raf (7): 158. Katakanlah: "Hai manusia sesungguhnya aku adalah utusan Allah kepadamu semua, yaitu Allah Yang mempunyai kerajaan langit dan bumi; tidak ada Tuhan (yang berhak disembah) selain Dia, Yang menghidupkan dan mematikan, maka berimanlah kamu kepada Allah dan Rasul-Nya, Nabi yang ummi yang beriman kepada Allah dan kepada kalimat-kalimat-Nya (kitab-kitab-Nya) dan ikutilah dia, supaya kamu mendapat petunjuk."

Sebenarnya kata ummiy - sebagaimana penelusuran Muji Basuki terambil dari kata umm menggambarkan kondisi seseorang dari segi pengetahuan seperti saat dia baru dilahirkan oleh ibunya. Kata umm sendiri muncul beberapa kali dalam Al-Qur'an. Dalam tesisnya yang berjudul "Ummiy dalam Al-Qur'an: Kajian Tematik Tafsir Al-Mishbah Karya M. Quraish Shihab,"23 Basuki mengungkapkan bahwa ayat ummiy muncul sebanyak 6 kali, yaitu 2 kali dalam bentuk tunggal (mufrad), dan 4 kali dalam bentuk jamak. Ayat-ayat ummiy yang berbentuk mufrad terdapat dalam surat makkiyah, yaitu Q.S. al-'Araafl7: 157 dan 158; dan berbentuk jamak terdapat dalam surat madaniyah, yaitu Q.S. alBaqarah/2: 78; Ali Imron/3: 20 dan 75; dan al-Jumu'ah/62:2.

\footnotetext{
${ }^{22}$ Maksudnya: dalam syari'at yang dibawa oleh Muhammad itu tidak ada lagi beban-beban yang berat yang dipikulkan kepada Bani Israil. Umpamanya: mensyari'atkan membunuh diri untuk sahnya taubat, mewajibkan kisas pada pembunuhan baik yang disengaja atau tidak tanpa membolehkan membayar diat, memotong anggota badan yang melakukan kesalahan, membuang atau menggunting kain yang kena najis.

${ }^{23}$ Muji Basuki, "Ummiy dalam Al-Qur'an: Kajian Tematik Tafsir Al-Mishbah Karya M. Quraish Shihab", Tesis (Surabaya: Program Studi Tafsir Pascasarjana, IAIN Sunan Ampel, 2013), hlm. abstrak.
} 
Dalam karyanya tersebut Basuki mengungkapkan bahwa: ${ }^{24}$ pertama makna ummiy dalam Al-Qur'an tidak bisa diukur dengan standar kebutahurufan (kebodohan) pada masa sekarang; kedua, makna ummiy adalah "tidak pandai membaca dan menulis"; ketiga dilihat dari konteks masing-masing ayat, maka kata ummiy menunjuk kepada dua golongan, yaitu golongan umat nabi-nabi sebelum Muhammad saw yang menerima kitab suci (Ahli Kitab), terutama sebagian umat Yahudi; dan golongan yang tidak mendapatkan, tidak mengetahui, dan tidak mengerti akan kitab-kitab samawi sebelum Al-Qur'an, di mana orang-orang Arab Jahiliyah dan Nabi Muhammad saw termasuk ke dalam golongan ini.

Dalam tema sama dengan sudut pandang yang berbeda, Usep Dedi Rostandi dalam tulisannya yang berjudul, "Konsep "Ummi" dalam alQur'an (Telaah Tematis)," 25 menyebutkan: pertama, bahwa ummiyin ditujukan kepada orang-orang yang mengingkari kerasulan nabi Muhammad saw, dalam hal ini Yahudi Madinah; kedua, ummiyin ditujukan untuk masyarakat Arab di zaman nabi Muhammad. Mereka ini dikenal sebagai orang yang tidak memiliki kitab suci. Ketiga, ummiy ditujukan kepada nabi Muhammad sebagai orang yang bukan Yahudi (non Yahudi) dan yang tidak pernah belajar Kitab-kitab Suci sebelumnya. Keempat, ummiy dengan demikian tidak bisa diterjemahkan dengan buta huruf, melainkan bisa baca tulis.

Menurut Wan Z. Kamaruddin bin Wan Ali, ${ }^{26}$ kata al-ummiy diartikan: Pertama orang yang tidak boleh menulis dan membaca; Kedua, diambil dari kata al-ummah yaitu keadaan umat manusia sebelum mereka mengetahui tentang menulis dan membaca terutama membabitkan umat Arab karena mereka menepati keadaan pada masa mereka dilahirkan; Ketiga, diambil dari kata al-umm, yaitu keadaan seseorang yang tidak mengetahui kedua-duanya, menulis dan membaca dilihat kepada keadaan

\footnotetext{
${ }^{24}$ Ibid.

${ }^{25}$ Usep Dedi Rostandi, “Konsep "Ummi” dalam al-Qur'an (Telaah Tematis)", Jurnal Falasifa, Vol. 5, No. 2, 2014, hlm. 291-299.

${ }^{26}$ Wan Z. Kamaruddin bin Wan Ali, "Konsep Ummi Nabi Muhammad saw dalam Perspektif al-Qur'an”, Jurnal Ushuluddin, tanpa Tahun, hlm. 150.
} 
pada masa mereka dilahirkan; Keempat, dirujukan pada umm al-Qurra yaitu kota Makkah.

Dua catatan penting dari Rostandi: ${ }^{27}$ pertama, bahwa sebelum terjadi perang Badar sempat terjadi kebocoran informasi di Nakhla. Karena itu untuk menjaga kerahasiaan ekspedisi di Nakhla diberi perintah dalam surat tertutup - yang berisi instruksi tertulis - yang tidak bisa dibuka hingga ia bergerak dari Madinah. Kedua, dalam perjanjian Hudaibiyah (628) nabi Muhammad menulis dengan tangannya sendiri. Wakil-wakil dari Mekkah menolak penyantuman kata Rasulullah, yang selanjutkan kata itu diganti dengan Ibn Abdullah. Pada mulanya Ali menolak untuk menggantinya, namun nabi Muhammad menggantinya dengan tangannya sendiri.

Secara khusus pada Q.S. al-A'raf/7: 157-158, gelar al-ummiy demikian menurut Hamka - pada nabi Muhammad bukanlah sebagai bentuk kehinaan, sebaliknya justru sebagai bukti kemuliaan. ${ }^{28}$ Sebagaimana dalam arti harfiah maupun pendapat para ulama lainnya, Hamka bersepakat bahwa al-ummiy diartikan dengan tidak pandai menulis dan membaca. Bukti ketidakmampuannya dalam hal baca tulis dialami ketika menerima wahyu pertama kali Q.S. al-Alaq ayat 1-5 yang disampaikan oleh Malaikat Jibril. Dengan terus terang beliau menjawab bahwa beliau tidak pandai membaca. ${ }^{29}$ Namun Roh beliau telah diberi keistimewaan oleh Allah, sehingga sanggup jiwa itu menerima wahyu ilahi. $^{30}$

Quraish Shihab pun ketika menguraikan arti al-ummiy tidak berbeda dengan Hamka, yaitu seseorang yang tidak pandai membaca dan

${ }^{27}$ Usep Dedi Rostandi, Op. cit, hlm. 291-299.

${ }^{28}$ Hamka, Tafsir al-Azhar,: PT Juz IX (Jakarta Pustaka Panjimas, 1985), hlm. 79.

${ }^{29}$ Hamka, Op. cit, hlm. 78.

${ }^{30}$ Hamka, Op. cit, hlm. 78. Lebih jauh Hamka menjelaskan bahwa bahwa hal itu bukanlah satu hal yang mengherankan; sedangkan seorang yang disebut orang "genius" orang-orang yang luar biasa yang lain, bisa mencapai martabat keduniaan yang tinggi, padahal buta huruf. Hamka menyebut Sultan Akbar di Hindustan yang buta huruf, tapi dikenal sebagai seorang filosof dan Raja Besar. Ibid. 
menulis. ${ }^{31}$ Shihab menjelaskan bahwa keadaan Rasulullah dalam keummiyan-nya, seakan-akan dari segi pengetahuan atau pengetahuan membaca dan menulis sama dengan keadaannya ketika baru dilahirkan oleh ibunya atau sama dengan keadaan ibunya yang tak pandai membaca. ${ }^{32}$ Lebih tegas Shihab menuliskan bahwa ke-ummiyyan nabi Muhammad sebagai salah satu bukti kerasulannya. Pendapat ini diperkuat dengan menyebut Q.S. al-Ankabut/29: 48, yang artinya sebagai berikut:

"Dan kamu tidak pernah membaca sebelumnya (Al Quran) sesuatu Kitabpun dan kamu tidak (pernah) menulis suatu Kitab dengan tangan kananmu; andaikata (kamu pernah membaca dan menulis), benar-benar ragulah orang yang mengingkari(mu)". (Q.S. alAnkabut (29): 48).

Al-Qur'an dan Tafsirnya terbitan UII Press pun juga mengartikan kata al-ummiy dengan tidak pandai menulis dan membaca. ${ }^{33}$ Keummiyan pada Nabi Muhammad memberi pengertian bahwa nabi Muhammad tidak mungkin membaca Taurat dan Injil yang ada pada orang-orang Yahudi dan Nasrani, demikian pula cerita-cerita kuno yang berhubungan dengan umat-umat terdahulu. ${ }^{34}$ Keummiyan nabi Muhammad dijadikan sebagai alasan kuat bahwa wahyu al-Qur'an yang diterima oleh nabi Muhammad bukan karena saduran atau tiruan dari Kitab-kitab dan cerita-cerita sebelum al-Qur'an.

Keterangan dari Tafsir ini dalam mengusik pemahaman penulis dengan pernyataan al-Qur'an yang menjelaskan bahwa salah satu persyaratan iman seseorang maka harus percaya pada Kitab-kitab yang diturunkan sebelum nabi Muhammad ${ }^{35}$ dan terkesan terdapat pemahaman

${ }^{31}$ M. Quraish Shihab, Tafsir al-Mishbah: Pesan dan Kesan Keserasan al-Qur'an, Val. 4 (Jakarta: Lentera Hati, 2002), hlm.324.

${ }^{32}$ M. Quraish Shihab, Op. cit, hlm.324

${ }^{33}$ Al-Qur'an dan Tafsirnya Jilid III, Juz 8-9, cet. ke-1, (Yogyakarta: UII Press, 2005), hlm. 481.

${ }^{34} \mathrm{Al}-\mathrm{Qur}$ 'an dan Tafsirnya Jilid III, Juz 8-9, hlm. 481

${ }^{35}$ Al-Baqarah/2: 4: 4. dan mereka yang beriman kepada Kitab (Al Quran) yang telah diturunkan kepadamu dan Kitab-kitab yang telah diturunkan sebelummu ${ }^{[17]}$, serta mereka yakin akan adanya (kehidupan) akhirat ${ }^{[18]}$. [17]. Kitab-kitab yang telah diturunkan sebelum Muhammad s.a.w. ialah kitab-kitab yang diturunkan sebelum Al 
yang bias bahwa al-Qur'an sebagai penyempurna Kitab-kitab sebelumnya, ${ }^{36}$ dan penjelas perselisihan di kalangan umat sebelum nabi Muhammad $^{37}$. Sebagai penyempurna, maka penyempurnaan dilakukan dengan diawali terlebih dahulu melakukan koreksi terhadap isi Kitabkitab sebelumnya.

Penulis mendukung pendapat tiga tafsir Indonesia di atas yang mengartikan kata al-ummiy dengan tidak pandai membaca dan menulis. Karena rangkaian kata ini menjelaskan tidak berarti Muhammad saw tidak paham tulisan, beliau pasti paham dan mengerti tulisan dan bacaan, hanya saja untuk mempunyai keahlian menulis dan membaca yang mumpuni memang dibutuhkan latihan yang lama dan berulang.

Quran seperti: Taurat, Zabur, Injil dan Shuhuf-Shuhuf yang tersebut dalam Al Quran yang diturunkan kepada para Rasul. Allah menurunkan Kitab kepada Rasul ialah dengan memberikan wahyu kepada Jibril a.s., lalu Jibril menyampaikannya kepada Rasul. [18]. Yakin ialah kepercayaan yang kuat dengan tidak dicampuri keraguan sedikitpun. Akhirat lawan dunia. Kehidupan akhirat ialah kehidupan sesudah dunia berakhir. Yakin akan adanya kehidupan akhirat ialah benar-benar percaya akan adanya kehidupan sesudah dunia berakhir.

36 Al-Maidah/5: 48. Dan Kami telah turunkan kepadamu Al Quran dengan membawa kebenaran, membenarkan apa yang sebelumnya, yaitu kitab-kitab (yang diturunkan sebelumnya) dan batu ujian ${ }^{[421]}$ terhadap kitab-kitab yang lain itu; maka putuskanlah perkara mereka menurut apa yang Allah turunkan dan janganlah kamu mengikuti hawa nafsu mereka dengan meninggalkan kebenaran yang telah datang kepadamu. Untuk tiap-tiap umat diantara kamu ${ }^{[422]}$, Kami berikan aturan dan jalan yang terang. Sekiranya Allah menghendaki, niscaya kamu dijadikan-Nya satu umat (saja), tetapi Allah hendak menguji kamu terhadap pemberian-Nya kepadamu, maka berlombalombalah berbuat kebajikan. Hanya kepada Allah-lah kembali kamu semuanya, lalu diberitahukan-Nya kepadamu apa yang telah kamu perselisihkan itu.

[421]. Maksudnya: Al Quran adalah ukuran untuk menentukan benar tidaknya ayat-ayat yang diturunkan dalam kitab-kitab sebelumnya. [422]. Maksudnya: umat Nabi Muhammad s.a.w. dan umat-umat yang sebelumnya.

37 An-Nahl/16: 63. Demi Allah, sesungguhnya Kami telah mengutus rasul-rasul Kami kepada umat-umat sebelum kamu, tetapi syaitan menjadikan umat-umat itu memandang baik perbuatan mereka (yang buruk), maka syaitan menjadi pemimpin mereka di hari itu dan bagi mereka azab yang sangat pedih. 64. Dan Kami tidak menurunkan kepadamu Al-Kitab (Al Quran) ini, melainkan agar kamu dapat menjelaskan kepada mereka apa yang mereka perselisihkan itu dan menjadi petunjuk dan rahmat bagi kaum yang beriman. 


\section{a. Awal Kesejarahan Muhammad saw}

Untuk memahami konsep an-nabiy al-ummiy, tidak bisa hanya merujuk pada makna kamus dan ayat-ayat yang terkait, namun perlu juga melibatkan istilah-istilah kekerabatan dalam budaya Arab, khususnya pada kehidupan yang terjadi menjelang dan saat kenabian Muhammad saw.

Kehidupan Muhammad saw, diawali dengan sejumlah peristiwa yang tidak umum dialami banyak orang. Dari perjalanan ayahnya - Abdullah bin Abdul Muthalib - sebagai anak yang terakhir dari sepuluh bersaudara, pernah dijadikan sebagai umpan nadzar oleh Abdul Muthalib untuk dijadikan korban (disembelih). Nadzar ini disampaikan oleh Abdul Muthalib sebagai konskuensi atas tradisi Arab Quraisy, jika memilih sepuluh orang anak salah satunya harus ada yang dijadikan korban. Ketika dilakukan undian berulang kali, namanya jatuh pada Abdullah. Namun berkat negosiasi dengan ahli nujum saat itu, nadzar tersebut bisa dibatalkan dengan penebusan 30 ekor unta. Dan Abdullah pun selamat dari korban budaya.

Setelah satu bulan istrinya hamil, Abdullah meninggal. Sehingga Muhammad saw lahir tanpa mengetahui wajah ayah kandungnya kecuali melalui cerita ibunya (Aminah) dan paman-pamannya serta kakeknya. Setelah lahirpun ia diserahkan penyusuannya kepada Tsuwaibah (sahaya Abu Lahab) dan Halimah Sa'diyah hingga usia lima tahun. Selama kurang lebih satu tahun Muhammad saw bersama ibunya. Di usia 6 tahun, ibunya wafat selanjutnya ia diasuh oleh kakeknya Abdul Muthalib (pemuka suku Quraisy yang dipercaya menjaga Ka'bah). Saat usia 8 tahun kakeknya wafat, selanjutnya hingga usia 25 tahun ia hidup bersama Abu Thalib (pamannya dari saudara bapaknya yang paling miskin sendiri).

Setidaknya terdapat peristiwa penting selama 17 tahun bersama pamannya. Pada usia 12 tahun Muhammad saw sudah diizinkan ikut kafilah dagang pamannya ke Syria. ${ }^{38}$ Selama perjalanan menuju Syria

${ }^{38}$ Maman A. Malik Sya'rani, "Peletakan Dasar-dasar Peradaban Islam Masa Rasulullah," dalam Siti Maryam, dkk. (ed.), Sejarah Peradaban Islam: dari Masa Klasik hingga Modern (Yogyakarta: LESFI, 2002), hlm. 22. Setibanya di Bushra, rombongan 
Muhammad saw mempunyai pengalaman yang tidak terlupakan: ${ }^{39}$ pertama, saat melintasi padang pasir yang luas di malam hari dengan menyaksikan bulan bintang yang bertebaran di langit serta kebunkebun yang subur dengan buah-buahan yang lebat yang berbeda dengan gurun pasir di sekitar Mekah. Kedua, didengarnya cerita di Syria tentang orang-orang Romawi beragama Nasrani, orang-orang Persia yang menyembah api, serta konflik yang melibatkan dua kerajaan Romawi dan Persia.

Pada usia 15 tahun Muhammad saw sudah dilibatkan dalam perang Fijar, perang antara Banu Kinanah dan Bani Quraisy. Ia membantu pamannya memungut anak panah yang dilontarkan musuh dan sesekali memanah ke arah musuh. Perang selama empat tahun yang berakhir dengan pembentukan perserikatan Sumpah Utama (Hilf al-Fudhul). Dalam perserikatan itu, Muhammad menjadi salah satu anggotanya termuda. ${ }^{40}$

Kegiatan lain yang dilakukan oleh Muhammad saw sebelum nikah adalah mengembala kambing. Pada bulan haram Muhammad diajak oleh keluarganya untuk mengunjungi Pasar Ukadz, Majannah dan Dzu alMajaz guna mendengarkan sajak-sajak. Dari para penyair itu Muhammad saw mendengarkan tentang sejumlah hal penting: ${ }^{41}$ pertama, kebanggaan terhadap nenek moyang bangsa Arab, serta jasa dan kebaikan mereka; kedua, propaganda orang Yahudi dengan kitab suci dan nabi Musa, serta propaganda orang Nasrani dengan kitab suci dan nabi Isa.

Pengalaman di bawah usia 24 tahun inilah menjadi bukti bahwa Muhammad saw telah terbiasa mendengar informasi dinamika sosial politik yang terjadi di luar wilayah Mekah dan akrab dengan gagasan-

dagang bertemu dengan Buhaira (Pendeta Kristen). Buhaira mengingatkan kepada Abu Thalib untuk menjaga Muhammad saw, karena pada dirinya terdapat tanda-tanda kenabian sebagaimana yang tertuang dalam Kitab Suci mereka. Buhaiara juga mengingatkan agar Muhammad saw tidak dibawa ke lingkungan Yahudi Syria, agar tidak dibunuh oleh mereka. Atas peringatan tersebut Abu Thalib pun mempersingkat kunjungan di Syria.

\footnotetext{
${ }^{39}$ Maman A. Malik Sya'rani, Op. cit., hlm. 22.

${ }^{40}$ Maman A. Malik Sya'rani, Op. cit, hlm. 23.

${ }^{41}$ Maman A. Malik Sya'rani, Op. cit, hlm. 23.
} 
gagasan keagamaan dan kesalihan yang ia terima dari para ahlinya, yaitu para penyair dan para agamawan. Apalagi kehidupannya di Mekah yang menjadi pusat dan lintasan dagang dari kota-kota besar lainnya. Tentu saja sebagai pedagang yang cerdas, informasi produk yang dibutuhkan oleh suatu masyarakat serta keadaan situasi keamanan lintasan yang dilalui oleh kafilah dagang akan senantiasa diupdate setiap musim.

Di usia 24 tahun Muhammad saw dipercaya oleh seorang saudagar perempuan yang kaya raya, Khadijah. Janda Quraisy yang kaya raya ini pada akhirnya mempersuamikan Muhammad saw pada saat masingmasing berusia 25 dan 40 tahun. sejak berstatus sebagai suami dari Khadijah, tentu saja Muhammad saw mempunyai kewenangan lebih luas daripada sebagai asisten. Namanya semakin populer di kalangan orangorang suku Quraisy. Kepopulerannya semakin memuncak ketika Muhammad saw berhasil melibatkan seluruh suku Quraisy dalam meletakkan Hajar Aswad di Ka'bah setelah tergeser dari tempatnya karena terkena banjir. Peristiwa sosial yang melibatkan sejumlah suku hingga memberinya gelar al-Amin ini terjadi ketika Muhammad saw berusia 35 tahun atau tepatnya pada tahun $605 .{ }^{42}$

\section{b. Mekah dan Posisi Lintas Budaya dan Perdagangan}

Kondisi Makkah pra Islam merupakan posisi strategis dalam persoalan ekonomi jalur persilangan ekonomi internasional yang menghubungkan jalur-jalur dari dan ke mancanegara. ${ }^{43}$ Letaknya yang strategis ini memainkan peranan $100 \%$ ikut berpartisipasi langsung dalam dunia perdagangan. ${ }^{44}$ Berikut secara rinci Karim menguraikan adanya empat jalur utama yang menjadikan Mekah sebagai titik sentralnya:

Pertama, dari Yaman yang menghubungkan antara Timur lewat jalur laut dengan Mekah; kedua, dari Damaskus (Syam) yang menghubungkan Asia Kecil dan Eropa Timur dengan Mekah; ketiga, Iraq (dalam perkembangan kemudian Baghdad) yang menghubungkan jalur darat ke Kabul, Kashmir, Singkiang/Sinjiang, sampai Canton dengan Mekah;

${ }^{42}$ Maman A. Malik Sya'rani, Peletakan Dasar-dasar Peradaban Islam Masa Rasulullah (Yogyakarta: LESFI, 2002), hlm. 24.

${ }^{43}$ M. Abdul Karim, Op. cit, hlm. 56.

${ }^{44}$ M. Abdul Karim, Op. cit, hlm. 58. 
keempat, dari Habsyi/Ethiopia sekarang ke Barat Daya dan pesisir Timur Afrika. ${ }^{45}$

Uraian di atas menjelaskan bahwa baik secara personal maupun kultural, pertumbuhan Muhammad saw akrab dengan tradisi intelektual dan ekonomi dari kalangan orang-orang Yahudi, Nasrani, dan Majusi. Apalagi kesan mendalam yang dia terima ketika menyaksikan kehidupan lain di luar tanah Arab yang subur dan makmur. Ini menunjukkan ada proses kulturasi, habituasi, dan internalisasi nilai-nilai budaya yang dialaminya secara langsung dalam arahan dan bimbingan pamannya.

\section{c. Umm, Al-Ummiy dan Budaya Arab}

Secara teologis-normatif, sebenarnya gelar Muhammad saw sebagai an-nabiy al-ummiy menjadi penegas kehadirannya sebagai utuasan Allah yang menjadi rahmat bagi sekalian alam (rahmatan lil'alamin). Hal itu sebagaimana tertuang dalam wa maa arsalnaaka illa rahmatan lil'alamin (Q.S. al-Anbiya/21: 107).

Setidaknya, tercatat dalam sejarah terdapat tiga fakta yang saling bertolak belakang dalam budaya Bangsa Arab, yaitu: pertama, terungkap sikap bangga kaum laki-laki yang dinasabkan (dibangsakan) kepada ibunya, sama dengan bila mereka dibangsakan kepada ayahnya. Mereka merasa bangga bila keturunan mereka dihubungkan kepada pihak ibu. ${ }^{46}$ Bahkan adat menjaga dan membela perempuan dan memandang kehormatan perempuan itu lebih tinggi harganya daripada jiwa, harta dan anak-anak. ${ }^{47}$ Kenyataan ini didukung dengan adanya beberapa kepala suku wanita, seperti Ummu Aufah, Kindah, dan sebagainya yang berdiam di Mekah, Madinah, Yaman, dan sebagainya. ${ }^{48}$

${ }^{45}$ M. Abdul Karim, Op. cit, hlm. 57.

${ }^{46}$ Hasan Ibrahim Hasan, Sejarah dan Kebudayaan Islam 1, terj. A. Bahauddin (Jakarta: Kalam Mulia, 2001),hlm. 114. Persaaan bangga menjadi nasab dari seorang Ibu, karena sebagian dari kalangan perempuan bangsawan Arab bisa bersuamikan 10 orang laki-laki. Jika hamil, tidak mungkin semua lelaki menghasilkan embrio bayi yang dikandung oleh istri mereka. Maka untuk menentukan siapa ayahnya mereka menjadi hak penuh sang ibu bayi tersebut atau ahli nujum yang ditunjuk. Lihat M. Abdul Karim, Sejarah dan Peradaban Islam (Yogyakarta: Pustak Book Publisher, 2012), hlm. 52.

${ }^{47}$ A. Syalabi, Sejarah dan Kebudayaan Islam 1, terj. Mukhtar Yahya (Jakarta: Pustaka al-Husna Baru, 2003), hlm. 60.

${ }^{48}$ M. Abdul Karim, Op. cit, hlm. 51. 
Kedua, kaum laki-laki - menurut Hamka mengutip Gaul Labon bisa beristri berapa pun yang dia suka dan menceriakan dengan sesuka hati pula. Bahkan istri-istri seorang lelaki Arab - di zaman itu dihukumkan sebagai barang warisan yang bisa diwariskan kepada anakanak mereka dari istri-istrinya yang lain. Sehingga bukan sedikit terdapat perkawinan di antara anak yang tua dengan istri ayah yang muda. ${ }^{49}$ Praktek ini telah diharamkan dalam Islam dan dipandang sebagai satu perkawinan yang cabul. Hal ini sebagaimana terungkap dalam Q.S. anNisa' $/ 4: 23 .^{50}$

Ketiga, selain itu perilaku buruk Arab Jahiliyah adalah menanam hidup-hidup anak perempuan (wa'dul banat) mereka. Namun tradisi ini hanya berlaku di dalam masyarakat kelas bawah karena takut miskin, terutama di kalangan Bani Asad dan Bani Tamim. ${ }^{51}$ Alasan lain dilakukannnya penguburan bayi perempuan hidup-hidup tidak lain mereka malu jika anak-anak perempuan mereka tumbuh akan bernoda dan ditawan musuh ${ }^{52}$ akan diperkosa beramai-ramai oleh suku yang

${ }^{49}$ Hamka, Sejarah Umat Islam (Singapura: Pustaka Nasional, PTE LTD, 2002), hlm.106.

${ }^{50}$ Arti: Q.S. al-Nisa/4: 23. Diharamkan atas kamu (mengawini) ibu-ibumu; anakanakmu yang perempuan ${ }^{[281]}$; saudara-saudaramu yang perempuan, saudara-saudara bapakmu yang perempuan; saudara-saudara ibumu yang perempuan; anak-anak perempuan dari saudara-saudaramu yang laki-laki; anak-anak perempuan dari saudarasaudaramu yang perempuan; ibu-ibumu yang menyusui kamu; saudara perempuan sepersusuan; ibu-ibu isterimu (mertua); anak-anak isterimu yang dalam pemeliharaanmu dari isteri yang telah kamu campuri, tetapi jika kamu belum campur dengan isterimu itu (dan sudah kamu ceraikan), maka tidak berdosa kamu mengawininya; (dan diharamkan bagimu) isteri-isteri anak kandungmu (menantu); dan menghimpunkan (dalam perkawinan) dua perempuan yang bersaudara, kecuali yang telah terjadi pada masa lampau; sesungguhnya Allah Maha Pengampun lagi Maha Penyayang.[281]. Maksud ibu di sini ialah ibu, nenek dan seterusnya ke atas. Dan yang dimaksud dengan anak perempuan ialah anak perempuan, cucu perempuan dan seterusnya ke bawah, demikian juga yang lain-lainnya. Sedang yang dimaksud dengan anak-anak isterimu yang dalam pemeliharaanmu, menurut jumhur ulama termasuk juga anak tiri yang tidak dalam pemeliharaannya.

${ }^{51}$ Hasan Ibrahim Hasan, Sejarah dan Kebudayaan Islam 1, hlm. 115. Lihat juga Hamka, Sejarah Umat Islam (Singapura: Pustaka Nasional, PTE LTD, 2002), hlm.106. Lihat juga M. Abdul Karim, Sejarah dan Peradaban Islam, hlm. 51.

\footnotetext{
${ }^{52}$ A. Syalabi, Op.cit., hlm. 61.
} 
menang dalam peperangan, ${ }^{53}$ rupanya tidak elok dan takut miskin, ${ }^{54}$ musuh mereka bunuh di mana mereka bertemu. ${ }^{55}$ Alasan takut miskin ini pula juga digunakan untuk melakukan penguburan pada bayi laki-laki terutama dari keluarga miskin dan kaum dhu'afa. ${ }^{56}$ Poin yang ketiga ini semakna dengan poin pertama, yaitu Bangsa Arab berusaha menghormati perempuan.

\section{Catatan Kritis}

Pemaparan letak yang strategis untuk Mekah ini sebagai imbangan fakta bahwa penduduk Mekah tidak berarti tidak mengerti budaya tulis menulis. Penjelasan al-nabiy al-ummiy kurang pandai membaca dan menulis, menggambarkan bahwa Muhammad saw tidak berarti tidak bisa sama sekali membaca dan menulis. Ini artinya beliau ada kemampuan memahami simbol tertulis, meskipun tidak mendalam. Namun dalam pertumbuhan Islam di Madinah lebih-lebih terkait dengan relasi antar umat Islam dengan Yahudi dan Kristen di Madinah yang selanjutnya diwujudkan dalam Piagam Madinah menunjukkan bahwa penjelasan annabiy al-ummiy bukan sebagai ulliterated prophet. Dalam konteks wahyu, mungkin nabi Muhammad tidak pernah menuliskannya atau tidak menulis wahyu yang diterimanya dari Allah melalui Malaikat Jibril, melainkan mendiktekannya.

Lantas bagaimana dengan an-nabiy al-ummiy bagi Muhammad saw? Kebutahurufan Muhammad saw bisa dipahami bahwa dalam kepiawaian tulis menulis memang beliau tidak pandai, tetapi tidak berarti dia tidak bisa membaca dan menulis. Terbukti bahwa sesuai dengan fakta kesejarahan konflik-konflik yang dihadapinya dengan orang Mekah (perjanjanjian Hudaibiyah, Piagam Madinah, serta surat-surat yang dikirim kepada penguasa di sekitar tanah Arab) menunjukkan keterlibatan Muhammad saw secara langsung dengan kegiatan tulis menulis.

\footnotetext{
${ }^{53}$ M. Abdul Karim, Op.cit., , hlm. 51.

${ }^{54}$ Hamka, Sejarah Umat Islam (Singapura: Pustaka Nasional, PTE LTD, 2002), hlm.88.

${ }^{55}$ Hamka, Sejarah Umat Islam (Singapura: Pustaka Nasional, PTE LTD, 2002), hlm.106.

${ }^{56}$ Hasan Ibrahim Hasan, Op.cit.,, hlm. 115.
} 
Selain itu, sebagaimana pengertian al-ummiy yang berdekatan degan istilah ummul Kitab, Muhammad saw bisa disebut sebagai Sumber Utama (the prime source) atau berperan sebagai Ibu Kandung Kewahyuan, sebagaimana peran seorang ibu pada umumnya. Mengapa? Pola pengasuhan dan pendidikan yang dilakukan oleh seorang ibu sejak awal menikah, hamil, melahirkan, mengasuh anak-anak, dan mendampingi mereka tidak perlu harus melakukan belajar secara khusus. Originalitas ajaran Muhamma saw sebagai indigenous (keaslian), sebagaimana aslinya seorang ibu.

Belum lagi gagasan ini jika dikaitkan dengan Nur Muhammad (the Light of Muhammad, al-Haqiqah al-Muhammadiyah). Hal ini mengingatkan penulis pada tokoh kontroversial al-Hallaj dengan hululnya. Al-Hallaj memaparkan tentang pandangannya mengenai eksistensi alam semesta melalui Nur Muhammad atau al-Haqiqah alMuhammadiyyah. Menurut al-Hallaj, nabi Muhammad saw memiliki dua esensi (al-haqiqah), yaitu al-haqiqah al-qadimah dan al-haqiqah alhaditsah. Esensi yang pertama sudah ada sejak sebelum alam semesta ini diciptakan. ${ }^{57}$ Esensi inilah yang menjadi sumber ilmu kearifan serta sebagai titik munculnya para nabi dan wali Allah. Adapun esensi yang kedua adalah wujudnya sebagai anak dari 'Abdullah bin 'Abd alMuthalib. ${ }^{58}$ Meskipun munculnya dari Nur al-'Azali al-Qadim, tetapi esensi yang kedua ini terbatas oleh ruang dan waktu. ${ }^{59}$ Berikut perkataan al-Hallaj:

Tha' Sin. Sinar cahaya gaib pun tampak dan kembali. Sinar itu pun melintasi dan mendominasi sesuatu. Sebuah bulan bersinar cemerlang di antara berbagai bulan, zodiaknya ada dalam bintang rahasia. Yang Maha Benar memberinya nama "Ummi" untuk

${ }^{57}$ Terhadap esensi yang terdahulu inilah sebagian kalangan Sufi memahami bahwa inilah Muhammad yang ditunjuk dalam bacaan tasyahud awal dan akhir pada kalimta "assalamu 'alaika ayyuha an-nabiyyu...". Konsep keabadian Muhammad ini pula yang juga menjadi penguat adanya persembahan shalawat dan salam yang ditujukan lepada Muhammad.

${ }^{58}$ Abu al-Wafa al-Ghanimi al- Taftazani, Sufi dari Zaman ke Zaman, terj. Ahmad Rofi' Utsmani, (Bandung: Penerbit Pustaka, 1997), hlm. 128-129.

${ }^{59}$ At-Taftazani, op.cit., hlm. 129 
menghimpun cintanya, "Hurmi" karena nikmat-Nya kepadanya, dan "Makki" karena ketetapannya pada kedekatannya. ${ }^{60}$

Perkataannya yang lain:

Cahaya-cahaya kenabian memancar dari cahayanya. Cahayacahaya mereka pun terbit dari cahayanya. Dalam cahaya-cahaya itu tidak satupun cahaya yang lebih cemerlang, gemerlap. Dan terdahulu, dari cahaya Pemegang Kemuliaan (Muhammad saw) ini. Cita-citanya lebih terdahulu ketimbang segala cita-cita. Wujudnya lebih terdahulu ketimbang ketiadaan. Dan namanya lebih terdahulu ketimbang kalam. Sebab telah ada sebelum makhluk-makhluk lain. ${ }^{61}$

Terhadap ide tentang Nur Muhammad inilah 'Abd al-Hakim Hassan dalam kitabnya at-Tasshawuf fi asy-Syi'ir al-'Arabiy, sebagaimana dikutip Simuh, mengatakan:

Al-Hallaj adalah orang yang mula-mula mengajarkan adanya Nur Muhammad, yaitu suatu konsep yang kemudian kadang disamakan dengan Logos (Firman) dan kadang pula disebut dengan al-Insan al-Kamil (Manusia Sempurna). Al-Hallaj mengajarkan bahwa mula pertama yang diciptakan Allah swt adalah Nur Muhammad terciptanya segala apa yang ada (dalam alam semesta) ini dan Nur Muhammad ini bersifat azali dan qadim mendahului setiap makhluk, sedang kedudukannya sebagai Rasul Allah adalah manusia bersifat baharu, menjadi penutup segala nabi. Di antara segala nur tidak ada nurnya segala nur nur yang amat terang dan qadim selain Nur Muhammad yang ada mendahului kehampaan (ketiadaan) dan namanya mendahuluyi Kalam, lantaran wujud sebelum adanya segala makhluk. ${ }^{62}$

${ }^{60}$ At-Taftazani, op.cit., hlm. 129.

${ }^{61}$ At-Taftazani, op.cit., hlm. 129.

${ }^{62}$ Simuh, Tasawuf dan Perkembangan Dalam Islam (Jakarta: PT. Raja Grafindo Persada, 1996), hlm. 148. Lihat juga Sahabuddin, Nur Muhammad Pintu Menuju Allah: Telaah Sufistik atas Pemikiran Syekh Yuduf an-Nabhani, cet. ke-2 (Yakarta: Logos Wacana Ilmu dan Pemikiran, 2002), hlm. 68. 
Ide Nur Muhammad ini pula yang menjadi dasar munculnya gagasan al-Hallaj tentang kesatuan agama-agama (wahdah al-adyan). Bagi alHallaj perbedaan agama-agama yang ada bukanlah pilihan setiap umat manusia, melainkan agama ditawarkan kepada manusia karena hal itu merupakan pilihan dari Tuhan.

'Abdullah ibn Tahir al-Azdi menuturkan tentang makiannya terhadap orang Yahudi yang diketahui al-Hallaj. Terhadap makian itu al-Hallaj tidak menyukainya. Namun setelah 'Abdullah ibn Tahir al-Azdi meminta maaf kepada al-Hallaj.

Dari uraian singkat di atas dapat dipahami secara sederhana bahwa Muhammad saw, selain karena dikaruniai kemampuan berpikir yang cerdas dan strategis, padanya sudah pasti mempunyai pengalaman yang mumpuni untuk melakukan tindakan-tindakan di atas. Artinya bahwa Muhammad saw, dalam gelar al-Qur'an sebagai an-nabiy al-ummiy memang bukan tipe pengarang melalui tulis menulis yang handal, tetapi berdasarkan pada perjalanan dan pengalaman hidupnya Muhammad saw sebagai pembelajar yang cerdik dan cerdas serta pertemuan yang dialaminya dengan sejumlah tokoh agama Yahudi dan Kristen serta perjumpaan interaktifnya dengan para kafilah dagang dari berbagai bangsa, menunjukkan bahwa pengalaman kesalihan dan kesantunan hidupnya senantiasa mendapat rujukan yang memadai berdasarkan pada tuturan orang pertama.

Penjelasan ini menegaskan bahwa dalam konteks wahyu tertulis Muhammad saw memang tidak melakukannya, namun isi kandungan dan nama-nama para nabi dan rasul yang sama baik dari dalam tradisi Yahudi, Kristen, maupun Islam sendiri didapatkannya dari para penutur pertama (penyair, pemeluk Yahudi dan Nasrani).

Penjelasan sufistik ini justru menjelaskan bahwa an-nabiy alummiypada Muhammad saw, kewahyuannya, otoritasnya dan keagungannya kerohaniannya tidak dibatasi oleh ruang dan waktu serta tradisi yang berkembang pada zaman sebelumnya dan zaman ketika hidup, sebaliknya dengan gelarnya an-nabiy al-ummiy inilah yang menjelaskan bahwa baik secara doktrin-peradaban, vertikal-horizontal, transenden-imanen, maupun normatif-historisnya melampaui dari semua 
perkiraan bukti tertulis yang ada. Karena an-nabiy al-ummiy itu sebagai sumber utama dan puncak kenabian dan kerasulan yang dalam bahasa alQur'an disebut penutup para nabi. Sebagaimana tertuang dalam Q.S. alAhzab/33: 40, yang artinya: 40. Muhammad itu sekali-kali bukanlah bapak dari seorang laki-laki di antara kamu, tetapi dia adalah Rasulullah dan penutup nabi-nabi. Dan adalah Allah Maha Mengetahui segala sesuatu.

\section{PENUTUP}

Isu seputar an-nabiy al-ummiy akan terus menjadi sasaran pertanyaan di kalangan muslim maupun non muslim. Karena sejumlah penjelasan yang dikemukakan oleh kalangan ulama sendiri tidak satu pandangan, selain memang istilah an-nabiy al-ummiy itu sendiri juga mengandung pertanyaan. Namun kajian demikan kajian harus dibuka sebagai upaya rasional ilmiah dan teologis, bahwa an-nabiy al-ummiy itu bisa dipahami bukan dalam konteks apologetis-teologis. Setidaknya berdasarkan pada pengkajian yang penulis lakukan, terdapat sejumlah pemahaman tentang istilah an-nabiy al-ummiy: pertama, jika al-nabiy al-ummiy dipahami dengan nabi buta huruf, jelas akan menolak fakta tentang keistimewaannya sebagai orang yang kecerdasannya melampai para umatnya. Kedua, relasi-interaksional antara nabi Muhammad dengan budaya Mekah (yang menjadi sentral perdagangan) dan budaya Madinah (yang menjadi pusat kesarjanaan Yahudi) menjadi bukti bahwa nabi Muhammad hidup dalam kegiatan ekonomi internasional dan budaya tulis menulis yang cemerlang. Implikasi dari pemahaman ini menunjukkan bahwa wahyu yang diterima nabi Muhammad bukan jatuh di ruang yang kosong. Wahyu tersebut melanjutkan yang sudah ada sekaligus penegas yang benar dan pengkoreksi yang salah. Ketiga, al-nabiy al-ummiy, bisa dipahami bahwa Muhammad saw sebagai pribadi yang sempurna dia menjadi sumber (babon), policy (kebijakan), dan wisdom (kebijaksanaan) baik yang bersifat vertikal maupun horizontal di kalangan umatnya. Kempat, berpijak pada realitas kesejarahan bangsa Arab yang bangga jika dinasabkan pada garis keturunan dari pihak Ibu, hal ini menegaskan 
bahwa nabi Muhammad adalah orang terhormat. Selain itu al-nabiy alummiy juga menjadi salah satu visi keislaman sebagai agama keibuan bahwa perempuan harus terhormat dan mendapatkan haknya. Kelima, alnabiy al-ummiy sebagai bukti bahwa nabi Muhammad memberi hukum tegas terhadap ibu-ibu (dari seorang suami) yang tidak boleh lagi diwariskan kepada anak-anak dari istri tuanya.

\section{DAFTAR PUSTAKA}

Armstrong, Amatullah. 1995. Sufi Terminology: al-Qamus al-Sufi) the Mystical Language in Islam. Kuala Lumpur: A.S. Noordeen.

Baalbaki, Rohi. 2001. al-Mawrid: Modern Arabic-English Dictionary. Libanon: Dar el Ilmlil Malayin.

Barnjart, C.L. (ed.). 1960. The American College Diactionary. New York: Random House.

Basuki, Muji. 2013. "Ummiy dalam Al-Qur'an: Kajian Tematik Tafsir Al-Mishbah Karya M. Quraish Shihab", Tesis. Surabaya: Program Studi Tafsir Pascasarjana, IAIN Sunan Ampel.

'Umar, Ahmad Mukhtar. 2007. Mu'jam al-Lughah al-'Arabiyyah alMu'ashir, al-Mujallad al-Awwal. Kairo: Alam al-Kutub.

Hamka. 2002. Sejarah Umat Islam. Singapura: Pustaka Nasional, PTE LTD.

Hamka. 1985. Tafsir al-Azhar, Juz IX. Jakarta: PT Pustaka Panjimas.

Hasan. Hasan Ibrahim. Sejarah dan Kebudayaan Islam 1, terj. A. Bahauddin. Jakarta: Kalam Mulia, 2001.

http://www.oxfordislamicstudies.com/article/opr/t125/e1680.

Karim, M. Abdul. 2012. Sejarah dan Peradaban Islam. Yogyakarta: Pustak Book Publisher.

Ma'luf, Luis. 1973. Al-Munjid: fi al-Lughah wa al-A'laam. Beirut: Dar al-Masyriq.

Munawwir, Ahmad Warson. 1984. Al-Munawwir: Kamis ArabIndonesia, Yogyakarta: Pondok Pesantren al-Munawwir Krapyak.

Neufeldt, Victoria (ed.). 1996. Webster's New World College Dictionary. USA: MacMillan.

Rostandi, Usep Dedi. "Konsep "Ummi" dalam al-Qur'an (Telaah Tematis)”, Jurnal Falasifa, Vol. 5, No. 02, 2014. 
Sahabuddin. 2002. Nur Muhammad Pintu Menuju Allah: Telaah Sufistik atas Pemikiran Syekh Yuduf an-Nabhani, cet. ke-2. Jakarta: Logos Wacana Ilmu dan Pemikiran.

Shihab, M. Quraish. 2002. Tafsir al-Mishbah: Pesan dan Kesan Keserasan al-Qur'an, Val. 4, Jakarta: Lentera Hati.

Simuh. 1996. Tasawuf dan Perkembangan Dalam Islam. Jakarta: PT. Raja Grafindo Persada.

Sya'rani, Maman A. Malik. 2002. "Peletakan Dasar-dasar Peradaban Islam Masa Rasulullah," dalam Siti Maryam, dkk. (ed.), Sejarah Peradaban Islam: dari Masa Klasik hingga Modern. Yogyakarta: LESFI.

Syalabi, A. 2003. Sejarah dan Kebudayaan Islam 1, terj. Mukhtar Yahya. Jakarta: Pustaka al-Husna Baru.

Taftazani al-, Abu al-Wafa al-Ghanimi. 1997. Sufi dari Zaman ke Zaman, terj. Ahmad Rofi' Utsmani. Bandung: Penerbit Pustaka.

Tim Departemen Agama RI. 2005. Al-Qur'an dan Tafsirnya Jilid III, Juz 8-9, cet. ke-1. Yogyakarta: UII Press.

Wan Ali, Wan Z. Kamaruddin bin, "Konsep Ummi Nabi Muhammad saw dalam Perspektif al-Qur'an," Jurnal Ushuluddin. [S.I], Vol. 7, 1998.

Wehr, Hans. 1976. A Dictionary Of Modern Written Arabic: ArabicEnglish. New York: Spoken Languge Service.

Yatim, Badri. 2002. "Muhammad SAW di Madinah," dalam Taufik Abdullah, Ensiklopedi Tematis Dunia Islam: Akal dan Awal. Jakarta: PT Ichtiar Baru van Hoeve. 